\title{
REPOSISI GURU PENDIDIKAN AGAMA ISLAM DI SEKOLAH DASAR KOTA MANADO
}

\author{
Rommy Cahya Nahu \\ Sekolah Dasar Negeri Pidung \\ Rommy.nahu@iain-manado.ac.id \\ Muh. Idris \\ Pascasarjana IAIN Manado \\ idristundru02@gmail.com \\ Ishak Talibo \\ Pascasarjana IAIN Manado \\ drishaktalibo123@gmail.com
}

\begin{abstract}
Abstrak: Penelitian ini bertujuan untuk menganalisis tentang posisi guru pendidikan agama Islam di Sekolah Dasar Kota Manado. Metode yang digunakan dalam membedah atau menganalisis penelitian ini adalah metode kualitatif untuk memberikan pemetaan posisi guru pendidikan agam Islam di Sekolah Dasar Kota Manado sebagai gambaran tentang bentuk reposisi guru agama Islam serta usaha yang dilakukan oleh pemerintah Daerah Kota Manado. Penelitian ini berlokasi di Sekolah Dasar Negeri di Kota Manado. Berdasarkan hasil penelitian ini ditemukan bahwa: Reposisi guru agama Islam di Sekolah Dasar Negeri Kota Manado terjadi karena adanya inisiasi guru agama Islam lainnya untuk mengisi posisi guru agama Islam dalam pembelajaran pendidikan agama Islam karena posisi guru agama Islam di posisikan oleh guru yang bukan berlatar belakang guru pendidikan agama Islam dan bahkan bukan guru yang beragama Islam. Selain itu reposisi guru agama Islam di Sekolah Dasar Negeri Kota Manado terjadi disebabkan adanya guru agama Islam mengambil jadwal mengajar di Sekolah lain yang tidak memiliki guru agama Islam guna untuk memenuhi kekurangan jam.
\end{abstract}

\begin{abstract}
This study aims to analyze about the position of Islamic education teachers in Elementary Schools in Manado city. The method used in dissecting or analyzing this research is a qualitative method. It is to provide a mapping of the position of Islamic education teachers in Manado City Elementary Schools as an illustration of the form of repositioning the Islamic education teachers and the efforts made by the local government of Manado City. This research is located at the State Elementary Schools in Manado City. Based on the results of this study, it is found that: The reposition of Islamic education teachers in Manado City Elementary Schools occurred due to the initiation of Islamic education teachers to reallocate Islamic education teachers in Islamic education learning because the position of Islamic education teachers was positioned by teachers who were not having educational teachers background and not even a Muslim teacher. In addition, the reposition of Islamic education teachers in Manado City Elementary Schools occurred due to the existence of Islamic education teachers in taking teaching schedules at other schools which do not have Islamic education teachers in order to meet the shortage of hours.
\end{abstract}

Kata Kunci: Reposisi, Guru Pendidikan Agama Islam, Sekolah Dasar. 


\section{Pendahuluan}

Pendidikan agama berstatus mata pelajaran pokok di Sekolah-sekolah umum mulai SD sampai dengan Perguruan Tinggi berdasarkan Undang-undang tentang sistem pendidikan nasional yang lebih menjamin pemenuhan pendidikan agama kepada peserta didik. UU Nomor 20 tahun 2003 pasal 30 berbunyi:

(1) Pendidikan keagamaan diselenggarakan oleh pemerintah dan /atau kelompok pemeluk masyarakat dari pemeluk agama, sesuai dengan peraturan perundangundangan. (2) Pendidikan keagamaan berfungsi mempersiapakan peserta didik menjadi anggota masyarakat yang memahami dan mengamalkan nilai-nilai ajaran agamanya dan menjadi ahli ilmu agama. (3) Pendidikan keagamaan dapat diselenggarakan pada jalur pendidikan formal, nonformal, dan informal. (4) Pendidikan keagamaan berbentuk pendidikan diniyah, pesantren, pasraman, pahhaja samanera, dan bentuk lain yang sejenis, Ketentuan mengenai pendidikan keagamaan sebagaimana disebutkan pada ayat (1), ayat (2), ayat (3), dan ayat (4) diatur lebih lanjut dengan peraturan pemerintah. ${ }^{1}$

Pendidikan agama Islam tidak tertuju kepada pembentukan akal saja, melainkan juga kepada setiap bagian jiwa sehingga setiap bagian jiwa itu mampu melaksanakan tugas sebagaimana dikehendaki oleh Allah swt. Sedangkan tujuan khusus pendidikan agama Islam ialah tujuan pendidikan agama pada setiap tingkatan. Untuk tingkat Sekolah Dasar, pendidikan agama Islam diberikan bertujuan untuk antara lain: menanamkan rasa agama terhadap peserta didik, menanamkan perasaan cinta kepada Allah dan rasul-Nya, memperkenalkan ajaran Islam yang bersifat global, membiasakan peserta didik berakhlak mulia, dan melatih peserta untuk merealisasikan ibadah yang bersifat praktis, serta membiasakan tauladan yang baik. ${ }^{2}$

Pendidikan Islam secara formal di Sekolah bukan sekedar mengajar pendidikan agama dan melatih ketrampilan siswa dalam melaksanakan ibadah akan tetapi pendidikan Islam lebih luas dari itu, pendidikan Islam bertujuan untuk membentuk kepribadian muslim siswa sesuai dengan ajaran agama Islam.

Posisi guru ialah merupakan orang dewasa yang merusaha mengalihkan pengetahuan, pengamalan, kecakapan dan ketrampilan oleh peserta didik. ${ }^{3}$ Posisi guru agama Islam ialah merupakan figur yang utama dalam menanamkan nilai-nilai luhur ajaran agama Islam dalam kerangka pembentukan sikap dan watak, serta perilaku peserta didik melalui berbagai model pembelajaran yang dikembangkan di Sekolah.

Pendidikan agama Islam mempunyai peran yang sangat strategis dalam mengembangkan potensi yang dimiliki peserta didik. Pendidikan agama Islam menekankan pada mempersiapkan generasi baru untuk dapat berperan dan mampu menjawab berbagai tantangan problematika hidup yang muncul serta memberikan solusi bagi kesejahteraan hidup umat manusia. Namun pada kenyataannya pelaksanaan pendidikan agama di Sekolah dianggap kurang berhasil dalam membina akhlak siswa salah satunya disebabkan oleh kurang

${ }^{1}$ UU Nomor 23 tahun 2003 Tentang Sistem Pendidikan Nasional dan UU No. 14 tahun 2005 Tentang Guru Dan Dosen (Jakarta : Visimedia, 2007), h. 9

${ }^{2}$ M. Arifin, Kapita Selekta Pendidikan, (Jakarta: Bumi Aksara, 2003), h. 27

${ }^{3}$ Abdul Majid, Belajar Dan Pembelajaran Pendidikan Agama Islam, (Bandung: Rosdakarya, 2012), h. 
perhatian dari pihak Sekolah terhadap posisi guru agama Islam yaitu adanya kekosongan guru agama Islam ataupun posisi guru agam Islam di isi oleh guru mata pelajaran yang lain yang tidak sesuai dengan latar belakang akademik. Padahal untuk mencapai tujuan pendidikan nasional, khususnya pada mata pelajaran pendidikan agama Islam yang akan dicapai yakni manusia yang beriman, bertakwa kepada Tuhan Yang Maha Esa dan berbudi pekerti luhur maka kiranya pembelajaran dalam pendidikan agama Islam dapat dilaksanakan secara efektif salah satunya dengan memaksimalkan posisi guru agama Islam yang harus sesuai dengan latar belakang pendidikannya.

Secara umum tantangan yang dihadapi guru di era globalisasi dan mordenisasi di masyarakat multikultural ini adalah bagaimana pendidikan mampu mendidik dan menghasilkan siswa yang memiliki daya saing tinggi (qualified) atau justru malah tak mampu dalam menghadapi gempuran berbagai kemajuan yang penuh dengan kompetensi dalam berbagai sektor, mampu menghadapi tantangan di bidang politik dan ekonomi, mampu melakukan riset secara komprehensif di era reformasi serta mampu membangun kualitas kehidupan sumber daya manusia. Setiap guru diharapkan mampu menjawab tantangan tersebut maka perlulah kompetensi yang diaktualisasi secara profesional dari seorang guru, hal ini secara tidak langsung menjelaskan bahwa posisi guru sangat tidak mudah dan tidak bisa digantikan dengan posisi profesi lainnya.

Di samping itu, dilihat dari segi aktualisasinya pendidikan merupakan proses interaksi antara guru dengan siswa untuk mencapai tujuan-tujuan pendidikan yang telah ditentukan. Guru, siswa dan tujuan pendidikan merupakan komponen utama pendidikan. Ketiganya membentuk triangle yang jika hilang salah satunya, maka hilang pulalah hakikat pendidikan. Namun demikian, dalam situasi tertentu posisi guru dapat dibantu oleh unsur lain seperti media teknologi tetapi tidak dapat digantikan secara keseluruhan apalagi digantikan dengan posisi guru yang bukan sesuai dengan mata pelajaran yang diajarkan. Oleh karena itulah, posisi guru sebagai pelaku utama dalam pendidikan yang merupakan seorang pendidik profesional dibidangnya tidak bisa digantikan oleh posisi lainnya demikian pula untuk posisi guru pada mata pelajaran pendidikan agama Islam karena dalam muatan pembelajarannya mengajarakan tentang penanaman konsep tauhid atau akidah . ${ }^{4}$

Demikian pula dengan hal kepribadian seorang guru . Kepribadian adalah keseluruhan dari individu yang terdiri dari unsur psikis dan fisik. Dalam makna demikian, seluruh sikap dan perbuatan seseorang merupakan suatu gambaran dari kepribadiannya dengan kata lain, baik tidaknya citra seseorang ditentukan oleh kepribadian. Apalagi posisi seseorang guru, kepribadian merupakan faktor yang menetukan terhadap keberhasilan melakukan tugas sebagai pendidik. Posisi guru sebagai teladan ialah harus memiliki kepribadian yang taat dijadikan idola karena seluruh kehidupannya adalah figur yang paripurna. Oleh karena itu kepribadian adalah masalah yang sangat sensitif sekali untuk posisi seorang guru, baik itu perkataan maupun perbuatan haruslah memberikan keteladanan untuk peserta didik terlebih untuk posisi guru agama Islam, kepribadian yang baik merupakan hal yang mutlak wajib dimiliki oleh seorang guru agama Islam karena guru agama Islam memiliki tanggung jawab yang lebih besar terkait nilai-nilai agama Islam yang ajarkan wajib pula ia lakukan oleh karena itu posisi guru agama Islam sangat tidaklah mudah maka tidak gampang untuk memposisikan diri sebagai guru agama Islam tapi tidak menutup kemungkinan untuk seseorang mengisi posisi tersebut yang penting ia mempunyai kompetensi yang sesuai dengan kompetensi guru agama Islam.

4 Nana Syaodih Sukmadinata, Pengembangan Kurikulum Teori dan Praktek, (Bandung: Remaja Rosdakarya, 1997), h. 191 
Posisi guru sebagai tenaga pendidik mempunyai fungsi, peran, dan kedudukan yang sangat strategis. Pasal 39 Ayat (2) Undang-undang nomor 20 Tahun 2003 tentang Sistem Pendidikan Nasional menyatakan bahwa pendidik merupakan tenaga profesional. Kedudukan guru sebagai tenaga profesional mempunyai visi terwujudnya penyelenggaraan pembelajaran sesuai dengan prinsip-prinsip profesionalitas untuk memenuhi hak yang sama bagi setiap warga negara dalam memperoleh pendidikan yang bermutu.

Menurut M. Rasyid Ridha dalam jurnalnya yang berjudul "Profesionalitas guru pendidikan agama Islam dalam proses pembelajaran" mengatakan bahwa:

Dalam konteks pendidikan agama Islam, profesionalitas guru berorientasi pada peningkatan kualitas dimensi personal dan sosial, termasuk juga pada adanya keseimbangan dengan peningkatan kualitas dimensi intelektual dan profesionalnya. Oleh karena itu, profesionalitas guru pendidikan agama Islam pada umumnya ditandai dengan beberapa karakteristik sebagai berikut: pertama, memiliki kepribadian yang matang dan berkembang karena bagaimanapun professionalism is predominantly an attitude, not only set of competencies; kedua, menguasai ilmu pengetahuan dan teknologi (bidang keahliannya) serta wawasan pengembangannya karena seorang guru yang akan menginspirasi siswanya kepada ilmu pengetahuan haruslah menguasai ilmu pengetahuan itu sendiri, tidak boleh setengah-setengah; ketiga, menguasai keterampilan untuk membangkitkan minat siswa kepada ilmu pengetahuan, dan keempat, siap mengembangkan profesi yang berkesinambungan, agar ilmu dan keahliannya tidak cepat tua atau out of date. 5

Ke empat karakteristik profesionalitas guru pendidikan agama Islam yang dikemukakan oleh M. Rasyid Ridha tersebut merupakan karakteristik yang harus dimiliki oleh setiap orang yang memposisikan diri sebagai guru agama Islam, jika karakteristik tersebut dapat dipenuhi maka seorang guru bisa dikatakan profesional dan bisa diposisikan sebagai guru agama Islam. Dari ke empat karakteristik tersebut dapat dipahami bahwa menjadi seorang guru agama Islam tidaklah mudah maka jika ada posisi guru agama Islam di isi oleh oleh guru yang tidak mempunyai karakteristik tersebut perlu adanya reposisi untuk mengisi posisi guru agama Islam tersebut.

Adapun penelitian ini berusaha melihat bagaimana reposisi guru pendidikan agama Islam yang terjadi Sekolah Dasar di Kota Manado. Penulis mengambil tempat Sekolah Dasar Negeri di Kota Manado sebagai tempat penelitian karena melihat terdapat dinamika posisi guru pelajaran pendidikan agama Islam tidak sesuai dengan posisinya sebagai perlu adanya reposisi guru pendidikan agama Islam. Pendidikan agama Islam yang seharusnya diajarkan oleh guru yang mempunyai latar belakang pendidikan agama Islam namun pada kenyataannya berbeda dengan apa yang terjadi di beberapa Sekolah Dasar Kota Manado yang posisi guru agama Islam digantikan oleh guru lainnya.

5 M. Rasyid Ridha. "Profesionalitas Guru Pendidikan Agama Islam dalam Proses Pembelajar," dalam Jurnal Tadris, Vol.3, No. 1, Januari-Juni 2008. 


\section{Landasan Teori}

Guru merupakan orang yang berwenang dan bertanggung jawab terhadap pendidikan murid-murid baik secara individual atau klasikal baik di sekolah maupun di luar sekolah. ${ }^{6}$ Guru tidak hanya mengajarkan pendidikan formal, tetapi juga menjadi sosok teladan bagi murid-muridnya. Bisa pahami bahwa mereposisi peran guru dengan tepat dapat menciptakan generasi penerus yang berkualitas dalam hal intelektual dan juga akhlaknya.

Posisi guru sebagai pendidik mempunyai peran sebagai pengajar, guru juga merasa bertanggung jawab kepada peserta didiknya baik itu secara akademis maupun psikologis. Tipe guru seperti ini yang umumnya dicintai oleh peserta didik dan benar-benar dapat memberikan dampak positif terhadap akhlak dan budi pekerti peserta didik.

Mereposisi guru untuk menjadi yang profesional memang tidaklah mudah karena harus memiliki berbagai kompetensi keguruan. Menurut Syaiful Sagala kompetensi adalah kemampuan melaksanakan sesuatu yang diperoleh melalui pendidikan dan latihan. ${ }^{7}$ Kompetensi guru meliputi kompetensi pedagogik, kepribadian, sosial, dan profesional yang diperoleh melalui pendidikan profesi.

Guru merupakan sebuah profesi yang merujuk pada pekerjaan atau jabatan yang menuntut keahlian, tanggung jawab, dan kesetiaan. Suatu profesi tidak bisa dilakukan oleh sembarang orang yang tidak dilatih atau dipersiapkan untuk itu. Profesi guru memiliki tugas melayani masyarakat dalam bidang pendidikan. ${ }^{8}$

Menurut Syaiful Bahri Djamarah mengatakan bahwa sesungguhnya posisi peran guru ialah sebagai pengajar, pendidik dan pembimbing serta masih ada berbagai peran guru lainnya. ${ }^{9}$ Dan peran guru ini senantiasa akan menggambarkan pola tingkah laku yang diharapkan dalam berbagai interaksinya, baik dengan peserta didik, guru maupun dengan staf yang lain. Dari berbagai kegiatan interaksi belajar mengajar, dapat dipandang guru sebagai sentral bagi perannya. Sebab baik disadari atau tidak bahwa sebagian dari waktu dan perhatian guru banyak di curahkan untuk menggarap proses belajar mengajar dan berinteraksi dengan peserta didiknya.

Posisi peran guru sebagai pendidik profesional sesungguhnya sangatlah kompleks karena tidak terbatas hanya pada saat berlangsungnya interaksi edukatif di dalam ruangan kelas. Hal yang sama dikemukakan oleh Akmal Hawi bahwa kurikulum kependidikan Islam bukan hanya sebatas didalam sekolah saja tapi terjadi setiap saat. ${ }^{10}$ Oleh karena itu seorang guru harus mampu siap sedia mengontrol peserta didik, kapan dan dimana saja anak didik berada.

Peranan guru dapat diartikan keseluruhan tingkah laku yang harus dilakukan guru dalam melaksanakan tugasnya sebagai guru. Peranan guru sangat melekat erat dengan pekerjaan seorang guru, maka pengajarannya tidak boleh dilakukan dengan seenaknya saja atau secara asal-asalan karena jika demikian akan berakibat fatal, menggagalkan peningkatan

\footnotetext{
${ }^{6}$ Muhaimin dkk, Strategi Belajar Mengajar, (Surabaya: Citra Media, 1996), h. 70

${ }^{7}$ Syaiful Sagala, Kemampuan Profesional Guru dan Tenaga Kependidikan, (Bandung: Alfabeta, 2009), h. 29. 2013), h. 1

${ }^{8}$ Sandy Abdullah, Penilaian Kinerja Profesi Guru dan Angka Kreditnya, (Yogyakarta, Gava Media,

${ }^{9}$ Syaiful Bahri Djamarah, Guru dan Anak Didik dalam Interaksi Edukatif, (Jakarta: Rineka Cipta, 2000), h. 37

${ }^{10}$ Akmal Hawi, Kompetensi Guru Pendidikan Agama Islam, (Jakarta: Raja Grafindo, 2013), h. 15
} 
mutu pendidikan. Seorang guru harus tau tugas dan perannya sebagai guru sehingga mampu memainkan peran pentingnya bagi keberhasilan peningkatan mutu pendidikan.

Posisi peran guru agama Islam adalah dapat diuraikan sebagai berikut:

\section{a. Posisi Guru sebagai Korektor}

Guru sebagai korektor yaitu guru harus bisa membedakan mana nilai yang baik dan mana nilai yang buruk. Kedua nilai yang berbeda itu harus betul-betul dipahami dalam kehidupan di masyarakat. Kedua nilai ini mungkin telah anak didik miliki dan mungkin pula telah mempengaruhinya sebelum anak didik masuk sekolah. Latar belakang kehidupan anak didik yang berbeda-beda sesuai dengan sosio-kultural masyarakat dimana anak didik tinggal akan mewarnai kehidupannya. ${ }^{11}$

Semua nilai yang baik harus guru pertahankan dan semua nilai yang buruk harus disingkirkan dari jiwa dan watak anak didik dengan menjadikannya habit atau kebiasaan yang terus-menerus dipraktikkan dan diamalkan. ${ }^{12}$ Bila guru membiarkannya, berarti guru telah mengabaikan perannya sebagai seorang korektor, yang menilai dan mengoreksi semua sikap, tingkah laku, dan perbuatan anak didik. Koreksi yang harus guru lakukan terhadap sikap dan sifat anak didik tidak hanya di sekolah, tetapi di luar sekolah pun harus dilakukan.

\section{b. Posisi Guru sebagai Inspirator}

Guru sebagai inspirator yaitu guru harus dapat memberikan ilham yang baik bagi kemajuan belajar anak didik. Persoalan belajar adalah masalah utama anak didik. Guru harus dapat memberikan petunjuk bagaimana cara belajar yang baik. Petunjuk itu tidak mesti harus bertolak dari sejumlah teori-teori belajar, dari pengalaman pun bisa dijadikan petunjuk bagaimana cara belajar yang baik yang penting bukan teorinya, tetapi bagaimana melepaskan masalah yang dihadapi anak didik. ${ }^{13}$

Dengan demikian guru yang mengambil peran sebagai inspirator, secara langsung dituntut untuk memiliki pengetahuan dan wawasan yang luas, luwes dalam berkomunikasi, rendah hati, selalu ingin belajar dan bekerja keras, fleksibilitas dalam bergaul, berani bersikap, memiliki prinsip dalam kebenaran, dan yang paling utama tidak merasa bosan menjadi seorang pendidik. ${ }^{14}$

Guru Sebagai inspirator, harus memberikan inspirasi bagi kemajuan belajar peserta didik. Persoalan belajar adalah masalah utama anak didik, guru harus dapat memberikan petunjuk bagaimana cara belajar yang baik.

\section{c. Posisi Guru sebagai Informator}

Guru Sebagai informator yaitu guru harus bisa memberikan informasi perkembangan ilmu pengetahuan dan teknologi, selain sejumlah bahan pelajaran untuk setiap mata pelajaran yang telah diprogramkan dalam kurikulum.

Guru sebagai pelaksana cara mengajar informatif dan sumber informasi dalam kegiatan akademik baik di kelas maupun di lapangan. ${ }^{15}$ Informasi yang baik dan efektif diperlukan dari guru. Kesalahan informasi adalah racun bagi anak didik. Untuk menjadi informatory yang baik dan efektif, penguasaan bahasalah sebagai kuncinya, ditopang

\footnotetext{
${ }^{11}$ Syaiful Bahri Djamarah, Guru dan Anak Didik dalam Interaksi Edukatif, h. 43-48.

${ }^{12}$ H.E Mulyasa, Managemen Pendidikan Karakter, (Jakarta: Bumi Aksara, 2012), h. 3

${ }^{13}$ A.M Sudirman, Interaksi dan Motivasi Belajar Mengajar, (Jakarta: Grafindo Persada, 2011), h. 144

${ }^{14}$ Nanang Fattah, Landasan Manajemen Pendidikan, (Bandung: Remaja Rosdakarya, 2011), h. 10

${ }^{15}$ A.M Sudirman, Interaksi dan Motivasi Belajar Mengajar, h. 144
} 
dengan penguasaan bahan yang akan diberikan kepada anak didik informator yang baik adalah guru yang mengerti apa kebutuhan anak didik dan mengabdi untuk anak didik.

d. Posisi guru sebagai organisator

Guru sebagai organisator adalah seorang pengelola kegiatan akademik, silabus, jadwal pelajaran, dan komponen-komponen yang berkaitan dengan kegiatan belajar mengajar digabung dan diorganisasikan sedemikian rupa. ${ }^{16}$ Hal ini merupakan sisi lain dari peranan yang diperlukan dari guru untuk mencapai efektivitas dan efisiensi kegiatan belajar peserta didik.

\section{e. Posisi Guru sebagai Motivator}

Guru sebagai motivator guru hendaklah dapat mendorong anak didik agar bergairah dan aktif belajar. Dalam upaya memberikan motivasi, guru dapat menganalisis motivmotiv yang melatarbelakangi anak didik malas belajar dan menurun prestasinya di sekolah. Setiap saat guru harus bertindak sebagai motivator, karena dalam interaksi edukatif tidak mustahil ada diantara anak didik yang malas belajar dan sebagainya. Peran guru sebagai motivator sangat penting dalam interaksi edukatif, karena menyangkut esensi pekerjaan mendidik yang membutuhkan kemahiran sosial, menyangkut performance dalam personalisasi dan sosialisasi diri. ${ }^{17}$ Motivasi dapat efektif bila dilakukan dengan memperhatikan kebutuhan anak didik. Penganekaragaman cara belajar memberikan penguatan dan sebagainya, juga dapat memberikan motivasi pada anak didik untuk lebih bergairah dalam belajar.

Guru sebagai motivator hendaknya dapat mendorong agar peserta didik mau melakukan kegiatan belajar, guru harus menciptakan kondisi kelas yang merangsang peserta didik melakukan kegiatan belajar, baik kegiatan individual maupun kelompok. Stimulasi atau rangsangan belajar para peserta didik bisa ditumbuhkan dari dalam diri peserta didik dan bisa ditumbuhkan dari luar diri peserta didik.

\section{f. Posisi Guru sebagai Inisiator}

Guru dalam perannya sebagai inisiator yaitu guru harus dapat menjadi pencetus ideide kemajuan dalam pendidikan dan pengajaran. Proses interaksi edukatif yang ada sekarang harus diperbaiki sesuai perkembangan ilmu pengetahuan dan teknologi di bidang pendidikan. Kompetensi guru harus diperbaiki, keterampilan penggunaan media pendidikan dan pengajaran harus diperbaharui sesuai kemajuan media komunikasi dan informasi abad ini. Guru harus menjadikan dunia pendidikan, khususnya interaksi edukatif agar lebih baik dari dulu. Bukan mengikuti terus tanpa mencetuskan ide-ide inovasi bagi kemajuan pendidikan dan pengajaran.

Dalam peranannya sebagai inisiator, guru harus dapat menjadi pencetus ide-ide kemajuan dalam pendidikan dan pengajaran. Proses interaksi edukatif yang ada sekarang harus diperbaiki sesuai perkembangan ilmu pengetahuan dan teknologi di bidang pendidikan. Kompetensi guru harus diperbaiki, keterampilan penggunaan media pendidikan dan pengajaran harus diperbaharui sesuai dengan kemajuan media komunikasi dan informasi abad ini. Guru harus menjadikan dunia pendidikan, khususnya interaksi edukatif agar lebih baik dari pada dulu. Bukan mengikuti terus tanpa mencetus ide-ide inovasi bagi kemajuan pendidikan dan pengajaran. ${ }^{18}$

Peserta didik merupakan sosok individu yang beragam tingkat intelektualitas, minat dan bakatnya. Mereka tidak mau dijadikan objek dalam pembelajaran, melainkan juga

\footnotetext{
${ }^{16}$ A.M Sudirman, Interaksi dan Motivasi Belajar Mengajar, h. 145

${ }^{17}$ Syaiful Bahri Djamarah, Guru dan Anak Didik dalam Interaksi Edukatif, h. 48.

${ }^{18}$ Akhyak, Profil Pendidik Sukses, (Surabaya: Elkaf, 2005), h.15
} 
harus dijadikan subjek. Tujuannya agar anak didik menjadi senang, simpati pada guru dan tidak menjenuhkan.

\section{g. Posisi Guru sebagai Fasilitator}

Pembelajaran dapat melibatkan dua pihak yaitu peserta didik sebagai pembelajar dan guru sebagai fasilitator. ${ }^{19}$ Yang menjadi dasar terpenting dalam kegiatan pembelajaran yaitu terjadinya proses belajar mengajar. Guru memberikan pelayanan dan bimbingan dalam rangka memudahkan peserta didik dalam mengikuti proses pembelajaran.

Peran guru sebagai fasilitator berdampak terhadap perubahan pola perilaku dari hubungan guru dengan peserta didik, peserta didik dengan peserta didik, maupun peserta didik dengan media pembelajaran. Hendaknya dalam memberikan pembelajaran jangan berpusat pada guru karena guru bukan satu-satunya sumber belajar yang utama. Peserta didik diberi kebebasan dalam mencari sumber belajar selain dari guru, karena hal ini akan melatih daya kreatifitas bagi peserta didik sehingga peserta didik menyenangi proses pembelajaran tersebut.

Guru sebagai fasilitator guru hendaknya dapat menyediakan fasilitas yang memungkinkan kemudahan kegiatan belajar anak didik. Lingkungan belajar yang tidak menyenangkan, suasana ruang kelas yang lengkap, meja dan kursi yang berantakan, fasilitas belajar yang kurang tersedia, menyebabkan anak didik malas belajar. Oleh karena itu menjadi tugas guru bagaimana menyediakan fasilitas, sehingga akan tercipta lingkungan belajar yang menyenangkan anak didik.

\section{h. Posisi Guru sebagai Pembimbing}

Guru berkewajiban memberikan bantuan kepada anak didik agar mereka mampu menemukan masalahnya sendiri, memecahkan masalah nya sendiri, mengenal diri sendiri, dan menyesuaikan diri dengan lingkungannya. Anak didik membutuhkan bantuan guru untuk mengatasi kesulitan-kesulitan pribadi, kesulitan pendidikan, kesulitan memilih pekerjaan, kesulitan dalam hubungan sosial, dan interpersonal. Karena itu, setiap guru perlu memahami dengan baik teknik bimbingan kelompok, penyuluhan individu, teknik mengumpulkan keterangan, teknik evaluasi, statistik penelitian, psikologi kepribadian, dan psikologi belajar. Jika murid menghadapi masalah di mana guru tak sanggup memberikan bantuan cara memecahkannya, baru minta bantuan kepada ahli bimbingan (guidance specialist) untuk memberikan bimbingan kepada anak yang bersangkutan. ${ }^{20}$

Peran guru yang tidak kalah pentingnya dari semua peran yang telah disebutkan di atas adalah sebagai pembimbing. Peran yang harus lebih dipentingkan, karena kehadiran guru di sekolah adalah untuk membimbing anak didik menjadi manusia dewasa susila yang cakap. Tanpa bimbingan, anak didik akan mengalami kesulitan dalam menghadapi perkembangan dirinya.

Kekurangmampuan anak didik menyebabkan lebih banyak tergantung pada bantuan guru. Tetapi semakin dewasa, ketergantungan anak didik semakin berkurang. Jadi, bagaimanapun juga bimbingan dari guru sangat diperlukan pada saat anak didik belum mampu berdiri sendiri (mandiri).

\section{i. Posisi Guru sebagai Pengelola Kelas}

Tugas guru sebagai pengelola kelas adalah melaksanakan administrasi kelas, melaksanakan presensi kelas, memilih strategi dan metode pembelajaran yang efektif. ${ }^{21}$

${ }^{19}$ Rudi Susilana dan Cepi Riyana, Media Pembelajaran Hakikat, Pengembangan, Pemanfaatan dan Penilaian. (Bandung: CV Wacana Kencana, 2009), h. 1

${ }^{20}$ Oemar Hamalik, Psikologi Belajar dan Mengajar, (Bandung, Sinar Baru Algesindo, 2004), h. 124

${ }^{21}$ Moh Uzer Usman, Menjadi Guru Profesional, (Bandung: PT Remaja Rosdakarya, 1999), h. 10 
Sebagai pengelola kelas, guru hendaknya dapat mengelola kelas dengan baik karena kelas adalah tempat berhimpun semua anak didik dan guru dalam rangka menerima bahan pelajaran dari guru. Permasalahan yang guru hadapi ketika berhadapan dengan sejumlah anak didik adalah masalah pengelolaan kelas. Apa, siapa, bagaimana, kapan, dan di mana adalah serentetan pertanyaan yang perlu dijawab dalam hubungannya dengan masalah pengelolaan kelas. ${ }^{22}$ Kelas yang dikelola dengan baik akan menunjang jalannya interaksi edukatif. Sebaliknya, kelas yang tidak dikelola dengan baik akan menghambat kegiatan pengajaran. Anak didik tidak mustahil akan merasa bosan untuk tinggal lebih lama di kelas. Hal ini akan berakibat mengganggu jalannya proses interaksi edukatif. Kelas yang terlalu padat dengan anak didik, pertukaran udara kurang, penuh kegaduhan, lebih banyak tidak menguntungkan bagi terlaksananya interaksi edukatif yang optimal.

Hal ini tidak sejalan dengan tujuan umum dari pengelolaan kelas yaitu menyediakan dan menggunakan fasilitas kelas bagi bermacam-macam kegiatan belajar mengajar agar mencapai hasil yang baik dan optimal. Berdasarkan kondisi demikian sangat diperlukan motivasi dari guru.

\section{j. Posisi guru sebagai evaluator}

Sebagai evaluator, guru dituntut untuk menjadi seorang evaluator yang baik dan jujur, dengan memberikan penilaian yang menyentuh aspek ekstrinsik dan intrinsik. Penilaian terhadap aspek intrinsik lebih menyentuh pada aspek kepribadian anak didik. Oleh karena itu guru harus bisa memberikan penilaian dalam dimensi yang luas. Jadi penilaian itu pada hakikatnya diarahkan pada perubahan kepribadian anak didik agar menjadi manusia susila dan cakap.

Sedemikian pentingnya evaluasi sehingga kelas yang baik tidak cukup hanya didukung oleh perencanaan pembelajaran, kemampuan guru mengembangkan proses pembelajaran serta penguasaannya terhadap bahan ajar dan juga tidak cukup dengan kemampuan guru dalam menguasai kelas tanpa diimbangi dengan kemampuan melakukan evaluasi terhadap perencanaan kompetensi peserta didik yang sangat menentukan dalam konteks perencanaan berikutnya atau kebijakan perlakuan terhadap peserta didik terkait dengan konsep belajar tuntas. ${ }^{23}$ Atau dengan kata lain, tidak ada satupun usaha untuk memperbaiki mutu proses belajar mengajar yang dapat dilakukan dengan baik tanpa disertai langkah evaluasi.

Setiap guru diharapkan untuk pandai-pandai mengarahkan kegiatan belajar peserta didik agar mencapai keberhasilan belajar (kinerja akademik) sebagai mana yang telah ditetapkan dalam sasaran kegiatan proses belajar mengajar karena inti dari peran guru dalam proses belajar mengajar ialah sebagai director of learning atau direktur belajar.

Demikian posisi peran guru yang harus dilakukan oleh seorang guru pendidikan agama Islam, selain itu ada empat (4) posisi fungsi guru sebagai pengajar yang berhubungan dengan cara pemeliharaan dan peningkatan motivasi belajar anak didik, yaitu guru harus dapat menggairahkan anak didik, memberikan harapan yang realistis, memberikan insentif dan mengarahkan perilaku anak didik ke arah yang menunjang tercapainya tujuan pengajaran.

a. Menggairahkan anak Didik

Dalam kegiatan rutin di kelas sehari-hari guru harus berusaha menghindari hal-hal yang monoton dan membosankan. Guru harus memelihara minat anak didik dalam belajar, 2013, h. 3

${ }^{22}$ Ishak Talibo, "Tipe-tipe Belajar dalam Proses Pembelajaran”, Jurnal Pendidikan Islam Iqra' 13,

${ }^{23}$ M. Ngalim Purwanto, Prinsip-Prinsip dan Teknik Evaluasi Pengajaran, (Bandung: PT. Remaja Rosdakarya,2004), h. 3 
yaitu dengan memberikan kebebasan tertentu untuk berpindah dari satu aspek ke lain aspek pelajaran dalam situasi belajar discovery learning dan metode sumbang saran (brain storming) memberikan kebebasan semacam ini. Untuk dapat meningkatkan kegairahan anak didik, guru harus mempunyai pengetahuan yang cukup mengenai awal setiap anak didiknya. $^{24}$

\section{b. Memberikan Harapan Realistis}

Guru harus memelihara harapan-harapan anak didik yang realistis dan memodifikasi harapan-harapan yang kurang atau tidak realistis. Untuk itu guru perlu memiliki pengetahuan yang cukup mengenai keberhasilan atau kegagalan akademis setiap anak didik di masa lalu. Dengan demikian, guru dapat membedakan antara harapan-harapan yang realistis, pesimistis, atau terlalu optimis.

\section{c. Memberikan Insentif}

Pemberian insentif merupakan sebuah imbalan yang diberikan berdasarkan tingkat prestasi yang dicapai oleh seorang yang dalam melakukan pekerjaannya, lembaga atau perusahaan yang menggunakan pemberian insentif untuk menghagai kinerja guru dan memotivasi seseorang atau kelompok dalam meningkatkan etos kerja untuk mencapai tujuan pendidikan. ${ }^{25}$

Bila anak didik mengalami keberhasilan, guru diharapkan memberikan hadiah kepada anak didik (dapat berupa pujian, angka yang baik, dan sebagainya) atas keberhasilannya, sehingga anak didik terdorong untuk melakukan usaha lebih lanjut guna mencapai tujuantujuan pengajaran. Insentif yang demikian diakui keampuhannya untuk membangkitkan motivasi secara signifikan.

\section{d. Mengarahkan Perilaku Anak Didik}

Nainggolan mencoba menjelaskan karakteristik dari perilaku, sebagai berikut: 1) dapat dipelajari, 2) bersifat konsisten, 3) bersifat pribadi, 4) Tidak sama pada setiap orang, 5) menyesuaikan diri dengan arah sosial, 6) mengandung aspek pengetahuan dan 7) berubahubah dalam perwujudannya. ${ }^{26}$

Mengarahkan perilaku anak didik adalah tugas guru. Guru dituntut untuk memberikan respons terhadap anak didik yang tak terlibat langsung dalam kegiatan belajar di kelas. Anak didik yang diam, yang membuat keributan, yang berbicara semaunya, dan sebagainya harus diberikan teguran secara arif dan bijaksana. Cara mengarahkan perilaku anak didik adalah dengan memberikan penugasan, bergerak mendekati, memberikan hukuman yang mendidik, menegur dengan sikap lemah lembut dan dengan perkataan yang ramah dan baik.

Dari penjelasan di atas dapat dipahami bahwasannya seorang guru mempunyai peran dan fungsi yang utama dalam pembelajaran peserta didik. Guru mempunyai tugas dan tanggung jawab yang besar khususnya guru pendidikan agama Islam, tugas guru pendidikan agama Islam tidak hanya mengajarkan materi-materi agam saja tetapi juga sebagai teladan

\footnotetext{
${ }^{24}$ Syaiful Bahri Djamarah, Psikologi belajar, (Jakarta : Rineka Cipta, 2002), h. 134-140

${ }^{25}$ Moeheriono, Pengukur Kinerja Berbasis Kompetensi, (Jakarta: Raja Grafindo Persada, 2012), h.

${ }^{26}$ J. M Nainggolan, Strategi Pendidikan, (Bandung: Generasi Info Media, 2008), 121.
} 
dan juga pembawa norma bagi anak didiknya dan juga sebagai orang tua kedua bagi anak didiknya.

Guru sebagai tenaga inti kependidikan memiliki tanggung jawab untuk mengembangkan potensi peserta didik secara maksimal dan membangun pertumbuhan yang dapat menunjang perkembangan peserta didik. Dengan demikian, guru harus memiliki modal dasar yaitu harus melaksanakan empat kompetensi diantaranya : kompetensi kepribadian, kompetensi sosial, kompetensi pedagogi dan kompetensi profesional untuk membangun pendidikan yang berkualitas.

Posisi guru sebagai tenaga pendidik mempunyai fungsi, peran, dan kedudukan yang sangat strategis. Pasal 39 Ayat (2) Undang-undang nomor 20 Tahun 2003 tentang Sistem Pendidikan Nasional menyatakan bahwa pendidik merupakan tenaga profesional. Kedudukan guru sebagai tenaga profesional mempunyai visi terwujudnya penyelenggaraan pembelajaran sesuai dengan prinsip-prinsip profesionalitas untuk memenuhi hak yang sama bagi setiap warga negara dalam memperoleh pendidikan yang bermutu.

Untuk menjadikan pendidikan bermutu merupakan tanggung jawab bersama. 3 Jalur pendidikan yaitu, pendidikan formal yang bertanggung jawab adalah guru, pendidikan informal yang bertanggung jawab adalah keluarga dan pendidikan non formal yang bertanggung jawab adalah semua elemen masyarakat. Jadi dalam dunia pendidikan semua orang sangat penting peranannya dalam meningkatkan pendidikan yang bermutu.

Dalam pendidikan yang paling ditekankan adalah prosesnya, karena pendidikan merupakan suatu proses pertumbuhan dan perkembangan yang berlangsung dari diri peserta didik karena itu pendidikan sangat menekankan pada proses, maka sebagai pendidik kita harus mengetahui bahwa tumpuan utama pendidikan ada pada pendidikan dan peserta didik.

Pendidikan merupakan proses pendewasaan bagi anak didik dan sebagai media pengembangan segenap potensi yang dimiliki sehingga pada akhirnya anak didik mampu mewujudkan cita-cita yang diinginkan. Dalam proses pendidikan Peserta didik sangat memerlukan pertolongan dari seorang guru dalam bentuk bimbingan, pembelajaran atau pelatihan supaya rohaninya (pikir, rasa, karsa, cipta dan budi nurani) berkembang dan jasmaninya (fisik dan panca indra) tumbuh sehat. Di situlah urgensi keberadaan guru sangat dipentingkan.

Kunci sukses pembelajaran adalah dengan menempatkan peserta didik sebagai subjek, bukan objek pembelajaran. Pembelajaran bisa efektif bila menempatkan peserta didik sebagai pusat kegiatannya. Sedangkan guru menghargai dan menghormati masing-masing pribadi peserta didik, keunikan, kemampuan dan potensi belajar mereka. Guru harus mampu dan memiliki kepekaan menangkap kata-kata dan bagaimana cara mengatakannya sehingga mudah dimengerti oleh peserta didik. Disinilah diperlukan kreatifitas dan kemampuan agar betul-betul bisa berbuat sesuai kebutuhan anak didik.

Guru sebagai tenaga inti kependidikan memiliki tanggung jawab untuk mengembangkan potensi peserta didik secara maksimal dan membangun pertumbuhan yang dapat menunjang perkembangan peserta didik. Dengan demikian, guru harus memiliki modal dasar yaitu harus melaksanakan empat kompetensi diantaranya : kompetensi kepribadian, kompetensi sosial, kompetensi pedagogi dan kompetensi profesional untuk membangun pendidikan yang berkualitas. 
Dalam menetapkan reposisi kebijakan guru ada beberapa hal yang dijadikan dasar acuan seperti guru harus menguasai materi yang akan diajarkan, mereka harus mempunyai pengetahuan lengkap dengan prinsip-prinsip psikologi, pendidikan dan sosiologi. Prinsipprinsip ini membuat mereka mampu memahami potensi-potensi fisik dan mental peserta didik yang sesuai dengan karakter, fungsi-fungsi serta pertumbuhan mereka. Hal ini harus sejalan dengan kwualitas pendidikan dan keakrabaan pendidik dengan penelitian-penelitian terbaru, serta norma-norma dari para pakar pendidikan. Guru harus mampu menerapkan serta menggali ilmu pengetahuan ini dalam proses pendidikan peserta didik untuk itu pendidik harus menjadi teladan yang baik dalam kepribadian dan tingkah laku. ${ }^{27}$ Menjadi seorang pendidik harus lebih cermat dalam menerapkan serta mengetahui apa yang ada dalam pendidikan.

Demikian pula dalam mereposisi kebijakan guru berdasarkan keprofesiolan dapat dilihat dari segi keilmuan, kemampuan teknis, komitmen moral yang tinggi dengan tugasnya. Ilmu pengetahuan kaitannya pendidikan yang profesional adalah pendidik yang memiliki ilmu pengetahuan dalam bidang yang diajarkannya, sehingga memungkinkan dia untuk mentransfer ilmu kepada peserta didiknya. Kemampuan teknis keguruan, dalam hal ini memiliki ketrampilan mengajar, misalnya persiapan mengajar, proses pembelajaran, sampai kepada evaluasi. Komitmen moral, berkenaan dengan sikap mental seorang pendidik meliputi cinta pekerjaannya, disiplin, objektif dan lain-lain. ${ }^{28}$

Dalam operasionalisasnya, reposisi kebijakan guru adalah memposisikan guru sebagai pendidik dalam rangkaian proses mengajar, memberi contoh, membiasakan, memuji, menghukum, memberi contoh, membiasakan dan lain sebagainya. ${ }^{29}$ Maka reposisi kebijakan guru menjadi kebijakan yang tepat dalam memposisikan guru karena tugas guru bukan hanya sekedar mendidik, disamping mendidik guru juga bertugas sebagai motivator dan fasilitator dalam proses belajar mengajar, sehingga dapat teraktualisasi secara baik dan dinamis. ${ }^{30}$

Hal lain yang harus diperhatikan oleh lembaga penyelenggara pendidikan adalah perlunya adanya kesinambungan antara tuntutan pemenuhan kewajiban terhadap para pendidik dengan memenui kebutuhan hak-haknya. Hal yang menjadi masalah di dunia pendidikan yaitu rendahnya gaji pendidik dibandingkan dengan profesi lainnya. ${ }^{31}$ Merupakan suatu ironi apabila pendidikan yang diakui oleh semua pihak sebagai profesi yang mulia tapi masih belum dimuliakan, profesi terhormat tapi belum dihormati, profesi yang sangat berharga tapi belum dihargai, dan profesi yang membawa kesejahteraan tapi belum disejahterakan

\section{Hasil Penelitian}

Kota Manado adalah ibu kota dari provinsi Sulawesi Utara. Manado yang berpenduduk mayoritas beragama Kristen, sedangkan Islam merupakan agama yang dianut ke 2 terbesar selain dari agama-agama lain yang ada di kota Manado, presentasi jumlah masyarakat yang 2003), h. 83

${ }^{27}$ H. Arief Rachman, Kiat-kiat Menjadi Generasi Unggul Seni Mendidik Islam, (Jakarta: Pustaka Zahra,

${ }^{28}$ Haidar Putra Daulay, Pendidikan Islam dalam Pendidikan Nasional di Indonesia, (Jakarta : Prenada Media, 2004), h. 77

${ }^{29} \mathrm{H}$ Muhaimin, Pengembangan Kurikulum Pendidikan Agama Islam di Sekolah, Maadrasah, dan Perguruan Tinggi, (Jakarta: PT Raja Grafindo Persada, 2014), h. 45

${ }^{30}$ Al Rasyidin dan H. Samsul Nizar, Pendekatan Historis, Teoritis dan Praktis Filsafat Pendidikan Islam, (Ciputat: TP Ciputat Press, 2005), h. 44

${ }^{31}$ Heri Jauhar Muchtar, Fikih Pendidikan, (Bandung: PT Remaja Rosdarya, 2008) h. 135 
Islam di kota Manado 37,78 \% sedangkan jumlah Kristen mencapai 54,31 \%. ${ }^{32}$ keberagaman dan kemajemukan yang ada pada masyarakatnya membuat Kota Manado kaya akan budaya.

Dengan demikian sangat perlu pendidikan dasar agama dalam menanamkan keagamaan dan keberagaman peserta didik di kota Manado terutama pendidikan agama Islam karena sebagai agama minoritas maka perlu adanya konsentrasi perhatian terhadap upaya memaksimalkan posisi guru agama Islam sebagai yang merupakan ujung tombak dari pendidikan agama Islam di Kota Manado. Adapun Kota Manado seperti yang telah dijelaskan sebelumnya bahwa Kota Manado mempunyai nilai-nilai keagamaan dan keberagamaan yaitu Torang samua basudara atau Torang samua ciptaan Tuhan, Nilai budaya Mapalus (Kerjasama), Sitou timou tumou tou, Nilai budaya demokrasi, Nilai budaya anti diskriminasi dan Nilai budaya silaturahmi. Semua itu dapat diaplikasi dengan tidak terlepas dari peran pendidikan terutama dalam penanam konsep nilai sejak Sekolah Dasar.

Kota Manado merupakan salah satu daerah otonomi yang mempunyai otoritas pengambil kebijakan dalam mengatur pemerintahan. Demikian pula dengan pendidikan di Kota Manado, pemerintah mempunyai tanggung jawab dan dituntut agar berperan aktif guna memajukannya dengan salah satunya pemenuhan guru di masing-masing satuan pendidikan dengan cara kebijakan pengangkatan guru THL ataupun usulan ke pusat terkait formasi kekurangan guru berdasarkan data dari masing-masing sekolah.

Adapun Kota Manado memiliki 442 Sekolah Dasar yang terdiri dari 165 Sekolah Dasar berstatus Negeri dan 277 sekolah dasar berstatus swasta. Seluruh sekolah dasar tersebut tersebar di 11 kecamatan. Sekolah Dasar yang berstatus negeri merupakan dasar penelitian yang dibahas sebelumnya dengan hasil pengamatan yaitu terdapat di 25 Sekolah Dasar Negeri yang terdapat di 6 kecamatan dari 11 kecamatan se Kota Manado yang perlu di reposisi terkait posisi guru agama Islam. ${ }^{33}$

Berdasarkan data 6 kecamatan tersebut maka peneliti mempetakan sekolah yang dominan disetiap kecamatan dengan hasil diketahui terdapat 3 kecamatan mendominasi terjadi reposisi guru agama Islam yaitu di kecamatan Malalayang terdapat 6 Sekolah Dasar Negeri, di kecamatan Tuminting terdapat 6 Sekolah Dasar Negeri dan di kecamatan Wanea terdapat 7 Sekolah Dasar Negeri.

Dari data tersebut di atas berdasarkan Sekolah Dasar Negeri yang menjadi rujukan perwakilan data penelitian yaitu Sekolah Dasar Negeri 93 Manado di kecamatan Wanea, Sekolah Dasar Negeri 70 Manado di kecamatan Malalayang, dan Sekolah Dasar Negeri 112 Manado di Kecamatan Tuminting.

\footnotetext{
${ }^{32}$ Sumber Daata :Dokumentasi Badan Pusat Statistik Sulawesi Utara tahun 2016.

${ }^{33}$ Sumber Data: Dokumentasi Dinas Pendidikan Dan Kebudayaan Kota Manado, tahun 2019.
} 
1. Reposisi Guru Agama Islam di Sekolah Dasar Negeri kota Manado

Guru merupakan suatu komponen yang penting dalam dunia pendidikan. Pendidikan yang berkualitas dapat mengantarkan masyarakat pada kecerdasan dan kemandirian. Untuk itu, diperlukan kerangka sistem penyelenggaraan pendidikan yang meliputi kejelasan arah kebijakan yang ditetapkan. Guru adalah sosok yang rela mencurahkan sebagian besar waktunya untuk mengajar dan mendidik siswa,

\begin{tabular}{|c|c|c|c|c|}
\hline \multirow[t]{2}{*}{ No. } & \multirow[t]{2}{*}{$\begin{array}{c}\text { Nama } \\
\text { Sekolah }\end{array}$} & \multicolumn{2}{|c|}{$\begin{array}{c}\text { Posisi } \\
\text { Guru PAI }\end{array}$} & \multirow[t]{2}{*}{ Keterangan } \\
\hline & & $\begin{array}{l}\text { Tidak } \\
\text { Ada }\end{array}$ & Ada & \\
\hline 1. & $\begin{array}{l}\text { SDN } \\
93 \text { Manado, } \\
\text { Kec. Wanea. } \\
\text { Kota Manado. }\end{array}$ & $\begin{array}{l}\text { Tahun } \\
2019\end{array}$ & $\begin{array}{c}\text { Tahun } \\
2020\end{array}$ & $\begin{array}{l}\text { 1. Posisi Guru PAI Tahun 2019: } \\
\text { - Elvina Y. Ma'ruf,. } \\
\text { - Pendidikan: SMA/Sederajat } \\
\text { 2. Reposisi Guru PAI Tahun 2020 : } \\
\text { - Suseni Monoarfa, S,Pd.I } \\
\text { - Pendidikan Agama Islam } \\
\text { 3. Bentuk Reposisi Guru PAI } \\
\text { - Inisiasi permohonan } \\
\text { tambahan jam mengajar. } \\
\text { - Intruksi tugas pengawaas } \\
\text { GPAI }\end{array}$ \\
\hline 2 & $\begin{array}{l}\text { SDN } \\
70 \text { Manado, } \\
\text { Kec. } \\
\text { Malalayang. } \\
\text { Kota Manado. }\end{array}$ & $\begin{array}{l}\text { Tahun } \\
2018\end{array}$ & $\begin{array}{l}\text { Tahun } \\
2019\end{array}$ & \begin{tabular}{|l} 
1. \\
- Tidakisi Guru PAI Tahun 2018: \\
meninggal dunia: Rahma \\
Amuna. \\
- Pendidikan : PGA \\
2. Reposisi Guru PAI Tahun 2019: \\
- Suriani Laha, S,Pd.I \\
- Pendidikan Agama Islam \\
3. Bentuk Reposisi Guru PAI \\
- Inisiasi permohonan \\
tambahan jam Mengajar. \\
- Intruksi tugas pengawaas \\
GPAI
\end{tabular} \\
\hline 3 & $\begin{array}{l}\text { SDN } \\
112 \text { Manado, } \\
\text { Kec. Tuminting. } \\
\text { Kota Manado. }\end{array}$ & $\begin{array}{l}\text { Tahun } \\
2018\end{array}$ & $\begin{array}{l}\text { Tahun } \\
2019\end{array}$ & $\begin{array}{l}\text { 1. Posisi Guru PAI Tahun 2018: } \\
\text { - Guru Kelas masing-masing. } \\
\text { - Pendidikan : PGSD } \\
\text { 2. Reposisi Guru PAI Tahun } 2019 \text { : } \\
\text { - Santy Malowa, S.Pd.I } \\
\text { 3. Bentuk Reposisi Guru PAI } \\
\text { - Inisiasi Permohonan } \\
\quad \text { Mengajar. }\end{array}$ \\
\hline
\end{tabular}

Sementara penghargaan dari sisi material, misalnya, sangat jauh dari harapan. Guru sangat berperan dalam membantu peserta didik untuk mewujudkan tujuan hidupnya secara optimal. Guru agama Islam berupah tanggung jawab terhadap perkembangan anak didik dengan mengupayakan perkembangan seluruh potensi anak 
didik, baik potensi efektif, potensi kognitif, maupun potensi psikomotorik. Oleh karena itu, guru sebagai orang dewasa yang bergerak di bidang pendidikan harus mampu untuk membimbing dan mendidik anak didik untuk mencapai tingkat kedewasaan, sehingga peserta didik memiliki bekal ketrampilan untuk hidup masyarakat dan siap menghadapi kehidupan dunia dan akhirat.

Keberadaan guru sangat berpengaruh dalam proses belajar mengajar. Oleh karena itu posisi guru harus diisi oleh orang-orang yang berkompeten dibidangnya sebab hanya seorang guru yang berkompeten yang mampu mengantarkan anak didik untuk menggapai cita-cita yang diharapkan.Oleh karena itu mengingat posisi guru sangat sakral terlebih posisi guru agama Islam maka sangat disesali jika posisi tersebut diisi dengan orang-orang yang tidak mengusai bidangnya seperti terjadi di beberapa Sekolah Dasar di kota Manado yang mengalami reposisi kembali terkait posisi guru agama Islam, sebagaimana tabel berikut:

Berdasarkan tabel di atas dapat dipahami bahwa telah terjadi reposisi guru pendidikan agama Islam di Sekolah Dasar Kota Manado yaitu dengan cara memposisikan kembali tugas dan fungsi guru pendidikan agama Islam dalam proses pembelajaran pendidikan agama Islam yang sebelumnya proses pembelajaran tersebut di posisikan oleh guru yang bukan berlatar belakang guru pendidikan agama Islam bahkan bukan beragama Islam.

2. Usaha Kepala Sekolah dalam mengisi kekosongan Guru Pendidikan Agama Islam di Sekolah Dasar Kota Manado.

Peningkatan kualitas pendidikan di sekolah dipengaruhi oleh berbagai faktor. Salah satu faktor yang paling dominan adalah kepemimpinan kepala sekolah. Kepala sekolah adalah sebagai agen perubahan yang dapat memimpin peningkatan kualitas pembelajaran. Kepala sekolah dapat memotivasi dan mendorong pendidik dan staf untuk meningkatkan kualitas dan kontribusinya dalam pembelajaran. Kepala sekolah dapat memberdayakan masyarakat untuk berperan aktif dalam peningkatan kualitas pembelajaran. Keberhasilan kepemimpinan kepala sekolah dalam mengelola dan mendayagunakan semua potensi yang ada, khususnya mengembangkan sumber daya manusia dan mengoptimalkan fasilitas sekolah akan berpengaruh besar terhadap kinerja pendidik dalam peningkatan kualitas pembelajaran sehingga berdampak positif pada kualitas peserta didik dan kinerja sekolah.

Demikian pula yang diharapkan oleh dunia pendidikan yang ada di Kota Manado, dalam hal peningkatan kualitas pendidikan di Kota Manado maka tentunya harus dibarengi dengan usaha kongkrit oleh masing-masing Kepala Sekolah dalam menciptakan stabilitas pembelajaran yaitu salah satunya memastikan keberadaan guru di Sekolah yang dipimpin. Adapun bila terjadi kekosongan guru maka kepala sekolah harus berusaha dalam mengisi kekosongan guru tersebut. 
Berikut tabel usaha kepala sekolah dalam mengisi kekosongan guru pendidikan agama Islam kota Manado.

\begin{tabular}{|c|c|c|c|}
\hline No. & $\begin{array}{c}\text { Nama } \\
\text { Sekolah }\end{array}$ & Usaha Kepala Sekolah & Keterangan \\
\hline 1. & $\begin{array}{l}\text { SDN } \\
93 \text { Manado, } \\
\text { Kec. } \\
\text { Wanea. } \\
\text { Kota } \\
\text { Manado. }\end{array}$ & $\begin{array}{l}\text { - Inisiasi Kepala Sekolah } \\
\text { mengajukan permohonan guru } \\
\text { tetap PAI ke Dinas Pendidikan } \\
\text { Kota Manado. }\end{array}$ & $\begin{array}{l}\text { Belum } \\
\text { direalisasi oleh } \\
\text { Dinas } \\
\text { Pendidikan Kota } \\
\text { Manado. }\end{array}$ \\
\hline 2 & $\begin{array}{l}\text { SDN } \\
70 \text { Manado, } \\
\text { Kec. } \\
\text { Malalayang. } \\
\text { Kota } \\
\text { Manado. }\end{array}$ & $\begin{array}{l}\text { - Inisiasi Kepala Sekolah } \\
\text { mengajukan permohonan guru } \\
\text { tetap PAI ke Dinas Pendidikan } \\
\text { Kota Manado. } \\
\text { - Inisiasi Kepala Sekolah } \\
\text { mengajukan permohonan guru } \\
\text { tetap PAI ke Kementerian Agama } \\
\text { Kota Manado }\end{array}$ & $\begin{array}{l}\text { Belum } \\
\text { direalisasi oleh } \\
\text { Dinas } \\
\text { Pendidikan Kota } \\
\text { Manado. }\end{array}$ \\
\hline 3 & $\begin{array}{l}\text { SDN } \\
112 \\
\text { Manado, } \\
\text { Kec. } \\
\text { Tuminting. } \\
\text { Kota } \\
\text { Manado. }\end{array}$ & $\begin{array}{l}\text { - Inisiasi Kepala Sekolah } \\
\text { mengajukan permohonan guru } \\
\text { tetap PAI ke Dinas Pendidikan } \\
\text { Kota Manado. }\end{array}$ & $\begin{array}{l}\text { Sudah } \\
\text { direalisasi oleh } \\
\text { Dinas } \\
\text { Pendidikan Kota } \\
\text { Manado. }\end{array}$ \\
\hline
\end{tabular}

Berdasarkan tabel di atas dapat dipahami bahwa terdapat usaha kepala sekolah dalam mengisi kekosongan guru tetap agama Islam di setiap Sekolah Dasar yang ada di kota Manado namun ada beberapa sekolah yang belum dapat direalisasikan oleh pemerintah Kota Manado.

\section{Penutup}

1. Reposisi guru agama Islam di Sekolah Dasar Negeri Kota Manado terjadi karena adanya inisiasi guru agama Islam lainnya untuk mengisi posisi guru agama Islam dalam pembelajaran pendidikan agama Islam karena posisi guru agama Islam di posisikan oleh guru yang bukan berlatar belakang guru pendidikan agama Islam dan bahkan bukan guru yang beragama Islam. Selain itu reposisi guru agama Islam di Sekolah Dasar Negeri Kota Manado terjadi disebabkan adanya guru agama Islam mengambil jadwal mengajar di Sekolah lain yang tidak memiliki guru agama Islam guna untuk memenuhi kekurangan jam mengajar. Dalam hal ini ada 165 Sekolah Dasar berstatus Negeri di Kota Manado yang tersebar di 11 kecamatan dan dari 165 Sekolah Dasar Negeri tersebut hanya 25 Sekolah Dasar Negeri yang perlu direposisi terkait keberadaan guru agama Islam di sekolah dasar tersebut.

2. Dalam reposisi guru agama Islam terdapat inisiasi guru agama Islam lainnya untuk mengisi posisi guru agama Islam dan adanya usaha kepala Sekolah, Dinas Pendidikan Kota Manado atau Kementrian Agama Manado dalam mengisi kekosongan guru pendidikan agama Islam di Kota Manado. Adapun kebijakan pemerintah Kota 
Manado dalam mengisi kekosongan guru pendidikan agama Islam yaitu dengan cara mengadakan pengangkatan guru agama Islam berstatus Tenaga Harian Lepas (THL) yang berkompetensi

\section{Daftar Pustaka}

Abdullah, Sandy. Penilaian Kinerja Profesi Guru dan Angka Kreditnya, Yogyakarta, Gava Media, 2013.

Akhyak, Profil Pendidik Sukses. Surabaya, Elkaf, 2005.

Arief Rachman, H. Kiat-kiat Menjadi Generasi Unggul Seni Mendidik Islam. Jakarta: Pustaka Zahra, 2003.

Arifin, M. Kapita Selekta Pendidikan. Jakarta: Bumi Aksara, 2003.

Bachtiar, Wardi. Metodologi Penelitian Ilmu Dakwah. Cet. I; Jakarta; Logos Wacana Ilmu, 1997.

Bahri Djamarah, Syaiful. Guru dan Anak Didik dalam Interaksi Edukatif. Jakarta: Rineka Cipta, 2000.

-------, Psikologi belajar. Jakarta : Rineka Cipta, 2002.

E. Mulyasa, M. Managemen Pendidikan Karakter. Jakarta: Bumi Aksara, 2012.

Fattah, Nanang. Landasan Manajemen Pendidikan. Bandung: Remaja Rosdakarya, 2011.

Hamalik, Oemar. Psikologi Belajar dan Mengajar. Bandung, Sinar Baru Algesindo, 2004.

Hawi, Akmal. Kompetensi Guru Pendidikan Agama Islam. Jakarta: Raja Grafindo, 2013.

IAIN Manado, Pedoman Penulisan Tesis .Manado, Pascasarjana, 2020.

M. Nainggolan, J. Strategi Pendidikan, Bandung: Generasi Info Media, 2008.

M. Sudirman, A. Interaksi dan Motivasi Belajar Mengajar. Jakarta: Grafindo Persada, 2011.

Majid Abdul, Majid, Belajar Dan Pembelajaran Pendidikan Agama Islam. Bandung: Rosdakarya, 2012.

Moeheriono, Pengukur Kinerja Berbasis Kompetensi, Jakarta: Raja Grafindo Persada, 2012.

Muhaimin dkk, Strategi Belajar Mengajar. Surabaya: Citra Media, 1996.

Ngalim Purwanto, M. Prinsip-Prinsip dan Teknik Evaluasi Pengajaran. Bandung: PT. Remaja Rosdakarya,2004.

Ridha, M Rasyid,. "Profesionalitas Guru Pendidikan Agama Islam dalam Proses Pembelajar," dalam Jurnal Tadris, Vol.3, No. 1, Januari-Juni 2008.

Sagala, Syaiful. Kemampuan Profesional Guru dan Tenaga Kependidikan. Bandung: Alfabeta, 2009.

Sugiono. Metode Penelitian Pendidikan (Pendekatan Kuantitatif, Kualitatif, dan R\&D). Bandung; Alfabeta, 2018.

-------, Memahami Penelitian Kualitatif. Bandung; Alfabetah, 2005.

Susilana, Rudi dan Cepi Riyana, Media Pembelajaran Hakikat, Pengembangan, Pemanfaatan dan Penilaian. Bandung: CV Wacana Kencana, 2009. 
Syaodih Sukmadinata, Nana. Pengembangan Kurikulum Teori dan Praktek, Bandung: Remaja Rosdakarya, 1997.

Talibo, Ishak. Tipe-tipe Belajar dalam Proses Pembelajaran, Jurnal Pendidikan Islam Iqra' 13, 2013.

UU Nomor 23 tahun 2003 Tentang Sistem Pendidikan Nasional dan UU No. 14 tahun 2005 Tentang Guru Dan Dosen. Jakarta : Visimedia, 2007.

Uzer Usman, Moh. Menjadi Guru Profesional. Bandung: PT Remaja Rosdakarya, 1999. 